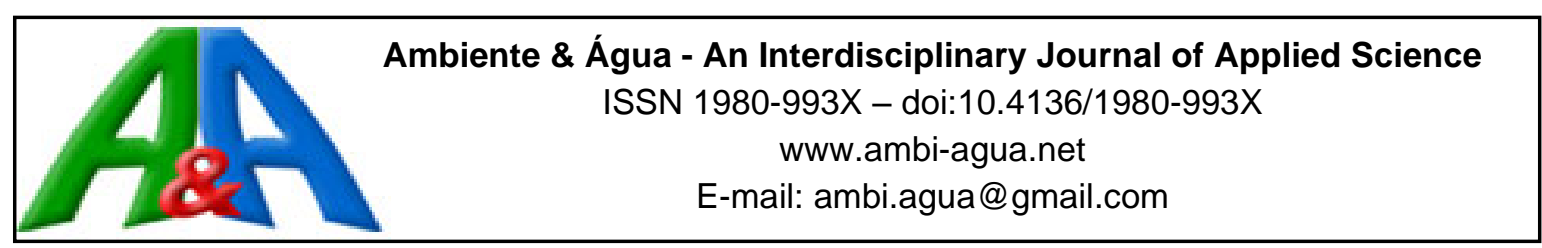

\title{
Future scenarios (2011-2040) of temporal and spatial changes in precipitation in the Paraitinga and Paraibuna watersheds, São Paulo, Brazil
}

\author{
doi:10.4136/ambi-agua.2302
}

Received: 10 Nov. 2019; Accepted: 15 Dec. 2019

\author{
Rodrigo Cesar da Silva*; Gilberto Fisch; Thiago Adriano dos Santos \\ Departamento de Ciências Agrárias. Universidade de Taubaté (UNITAU), Est. Mun. Dr. José Luiz Cembranelli, \\ $\mathrm{n}^{\circ}$ 5000, CEP: 12081-010, Taubaté, SP, Brazil. \\ E-mail: fisch.gilberto@gmail.com, thiagoadrianodossantos@hotmail.com \\ *Corresponding author. E-mail: rodrigo.peb@gmail.com
}

\begin{abstract}
The alteration of global climate regimes due to anthropic action and excessive emission of greenhouse gases has been widely researched because it alters the patterns of climatological normals, generating changes in temperatures and precipitation worldwide. This study aimed to analyze the spatial and temporal variability of precipitation in the Paraitinga and Paraibuna watersheds that together form the Paraibuna Dam, the main one of the Paraiba do Sul river watershed. This dam supplies the São Paulo Metropolitan Region by transporting water to the Cantareira System, the Rio de Janeiro Metropolitan Region by transporting water to the Guandu watershed, and the Paraiba Valley Metropolitan Region, one of the most industrialized in Brazil. To investigate future precipitation trends, past and future climate simulations were used from the HadCM3/Eta model using the SRES (Special Report Emission Scenarios) A1B, and precipitation analysis using Quantis techniques to determine extreme rainfall and drought periods. The results point to an increase in precipitation averages in the region, followed by a greater intensity of extreme rainfall, which may lead to a higher occurrence of natural disasters such as landslides.
\end{abstract}

Keywords: climate simulation, HadCM3, Paraiba Valley, SRES.

\section{Cenário futuro (2011-2040) de mudanças temporais e espaciais na precipitação ao longo da bacia dos rios Paraitinga e Paraibuna, São Paulo, Brasil}

\section{RESUMO}

A alteração dos regimes climáticos globais em função da ação antrópica e da emissão excessiva de gases do efeito estufa tem sido amplamente pesquisado pois altera os padrões da normal climatológica, gerando modificações nas temperaturas e precipitação em todo o mundo. Para tanto, esta pesquisa busca analisar a variabilidade espacial e temporal da precipitação ao longo das bacias dos rios Paraitinga e Paraibuna que juntas formam a represa de Paraibuna, a principal da bacia hidrográfica do rio Paraíba do Sul, e que abastece a Região Metropolitana de São Paulo por meio de transposição de água para o Sistema Cantareira, a Região Metropolitana do Rio de Janeiro por meio da transposição para a bacia do rio Guandú e a Região Metropolitana 
do Vale do Paraíba, uma das mais industrializadas do Brasil. Para investigar as tendências futuras de precipitação foram utilizados dados de simulação climática do passado e futuro do modelo HadCM3/Eta, SRES (Special Report Emission Scenarious) A1B, e também a análise de precipitação por meio das técnicas dos Quantis para determinar chuvas extremas e períodos de seca. Os resultados apontam para um aumento das médias de precipitações na região, seguida de uma maior intensidade de chuvas extremas, o que poderá acarretar uma maior ocorrência de desastres naturais relacionados a escorregamento de massas.

Palavras-chave: HadCM3, simulação climática, SRES, Vale do Paraíba.

\section{INTRODUCTION}

Technological modernization and the development of industrial activities resulting from the Industrial Revolution has accelerated the emission of greenhouse gases, which aggravates this natural phenomenon, changing climate regimes on a planetary scale (IPCC, 2019). One of the climatic elements that is influenced is precipitation, an element of fundamental importance for the existence and maintenance of life on Earth (TEIXEIRA, 2009).

In a study on climate change scenarios for South America, Chou et al., (2014) conducted simulations using two global models, HadGEM2-ES and MIROC5, considering two distinct RCP scenarios (4.5 and 8.5), regionalized by the Eta model. The data indicate that there will be a downward trend in precipitation totals at the end of the $21^{\text {st }}$ century for the Brazilian CenterSouth region in the areas that are occupied by the South Atlantic Convergence Zone. The data also suggest that there will be a downward trend in the frequency of occurrence of the SACZ and a reduction of the moisture transfer capacity of the Amazon with a respective decrease in precipitation production, allied to an increase of high-pressure zones in the southeast region.

Lyra et al., (2017) analyzed climate change projections for the metropolitan regions of São Paulo, Rio de Janeiro and Santos by the end of the $21^{\text {st }}$ century using the HadGEM2-ES climate simulation model regionalized by the Eta model with a $5 \mathrm{~km}$ resolution. They noted that there will be a trend of an average increase in temperature above the normal climate of up to $8^{\circ} \mathrm{C}$ for the 2017-2100 period, coupled with a considerable decrease in rainfall during the summer period, ranging from 3 to $6 \mathrm{~mm} / \mathrm{day}^{-1}$ by the end of the century, followed by an increase in extreme rainfall in the mountainous areas of the region, although accompanied by a general decrease in precipitation rates. Such extreme event associations could impact the region's water reservoirs and affect water availability for human consumption and power generation.

In a study on climate change in the municipality of Taubate/SP, located in the Paraiba Valley region, Horikoshi and Fisch (2007) used climate simulation data from the HadCM3 model, using SRES A1 and B1 for the study area, which indicated a rise in temperature between $0.5^{\circ}$ to $2.7^{\circ} \mathrm{C}$ by the end of the $21^{\text {st }}$ century. This was followed by an increase in average rainfall, with a tendency to decrease in the summer and increase in the winter, causing a trend of increasing water deficit for the region until the end of the century.

Santos and Fisch (2016) when analyzing the future trend of precipitation and temperature for the municipality of Taubate/SP, using the HadCM3 simulation model, SRES A1B, indicate that by the end of the century there will be an increase in daily precipitation averages for all months. followed by an increase in total precipitation averages with a tendency to rain concentration in the rainy season and an increase in maximum rainfall occurrences, indicating a future with greater presence of extreme rainfall.

Considering the future trends of changes in climate behavior for the southeastern region of Brazil, specifically for the Paraiba do Sul watershed, which is located among the main and most economically developed regions of the country, this study aims to analyze the precipitation regime for the Paraitinga and Paraibuna watersheds, which form the Paraibuna dam, and 
describe the spatial and temporal distribution of this climatic element, pointing to future trends of persistence of extreme rainfall and drought periods.

\section{MATERIALS AND METHODS}

\subsection{Study area}

The study was carried out in the Paraitinga and Paraibuna watershed, which together form the Paraibuna dam and are part of the Paraiba do Sul watershed, one of the most important of Brazil, located between three of the main metropolitan regions of the country, São Paulo, Rio de Janeiro and the Paraiba Valley (SILVA and FISCH, 2019).

The waters of this watershed are extremely important because they are transported to the Metropolitan Region of Sao Paulo through the Cantareira System, are used as the main water source in the Paraiba Valley Metropolitan Region and provide water to the Rio de Janeiro Metropolitan Region through the transposition of water to the Guandu watershed. The area of the Paraitinga and Paraibuna watershed is $4437.5 \mathrm{~km}^{2}$, and at the end of these basins is the Paraibuna Dam, located in the municipalities of Redenção da Serra, Natividade da Serra and Paraibuna, in the State of São Paulo. The study area is shown in Figure 1.

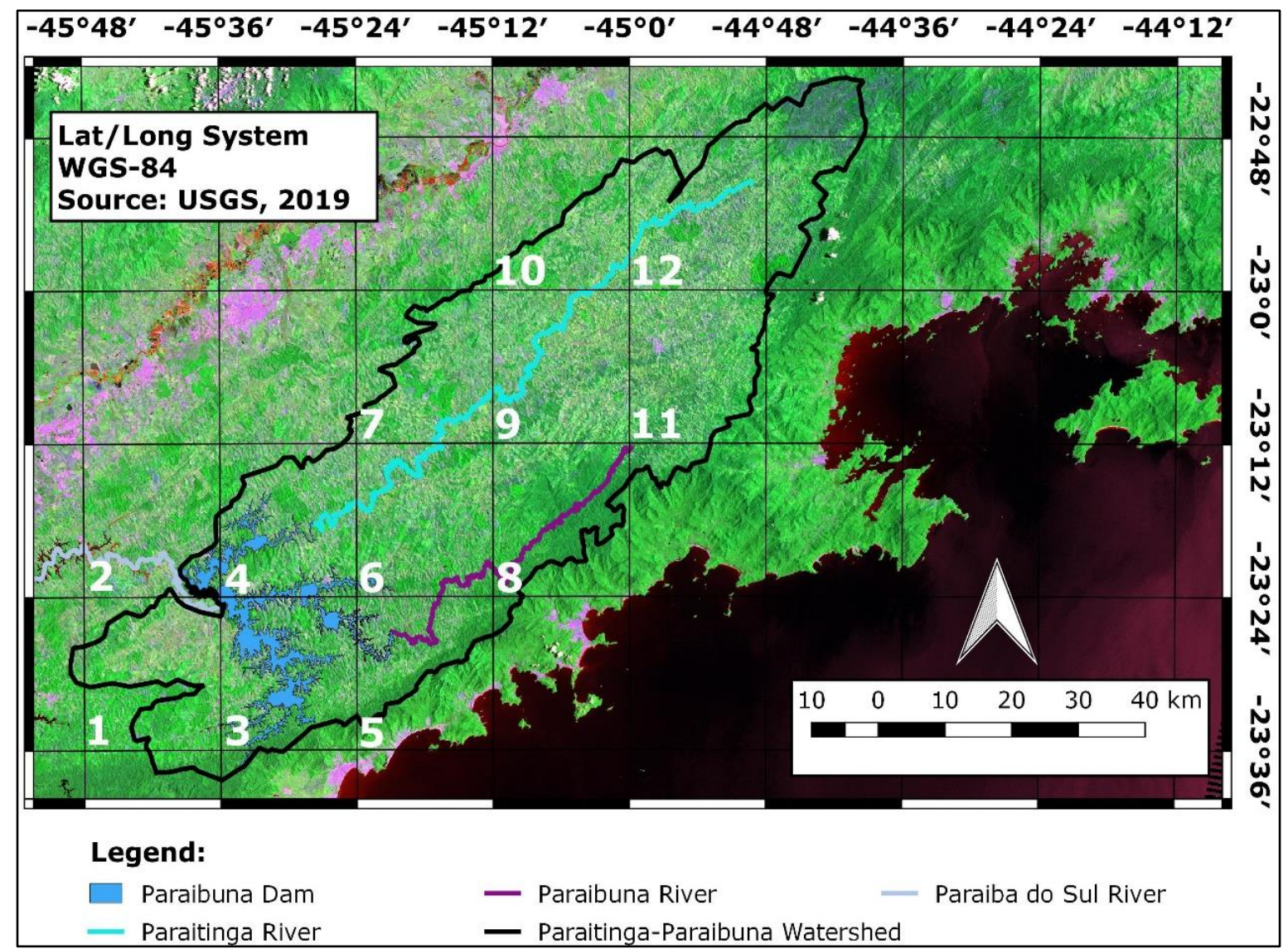

Figure 1. Study area and climate simulation grids.

\subsection{Climate Simulation}

The precipitation data used in this study were generated from climate simulation data from the HadCM3 model, regionalized by the Eta model, which was developed by the British Meteorological System. Data were simulated considering the SRES (Special Report Emission Scenarios) A1B of IPCC in its fourth report (IPCC, 2007), with a resolution grid of 20x20km. This future scenario is compatible with the RCP (Representative Concentration Pathway) 4.5 of the IPCC in its fifth report (IPCC, 2013; SANTOS and FISCH, 2016). 
Two temporal cut-offs were considered, one from a past period (1961-1990) and the other from a future period (2011-2040). Daily rainfall values, monthly and annual averages, rainy season averages (from October to March) and summer period averages (DJF) were analyzed. The simulated precipitation values are homogeneous across the simulation grid area of $400 \mathrm{~km}^{2}$, differing in each simulation grid.

\subsection{Determination of dry years and daily extreme rainfall}

For the determination of dry and very dry years, and extreme rainfall, the Quantis technique was used, which was initially developed by Pinkayan (1966) and widely used in other studies (XAVIER et al., 2007; MONTEIRO et al., 2012).

According to Xavier et al. (2002), the Quantis technique is a method based on a series of precipitation data $(\mathbf{x})$, where the total precipitation in a given year is considered to be a random variable, and the Quantil $\left(\mathbf{Q}_{\mathbf{x}}\right)$ represents a percentage variation of precipitation $(\mathbf{x})$ as a function of $(\mathbf{Q})$.

According to Pinkayan (1966) the distribution of precipitation depends on physiographic factors and atmospheric circulation, with dry or rainy years occurring as a function of precipitation variability, reservoir water stock and moisture contained in the air. The precipitation distribution is defined by Equation 1; when $\mathrm{F}(\mathrm{x})$ is known for $\mathrm{x}_{1}, \mathrm{x}_{2}, \mathrm{x}_{3}, \mathrm{x}_{4}$ and $\mathrm{x}_{5}$, the Quantis are determined considering Table 1.

$$
F(x)=P[X \leq x]
$$

Table 1. Application of Quantis technique to precipitation classification.

\begin{tabular}{cccc}
\hline Function & Quantis & Classification & Variation \\
\hline $\mathrm{F}\left(\mathrm{x}_{1}\right) 0.15$ & $\mathrm{Q}(0.15)$ & Very dry & $\mathrm{x} \leq 0.15$ \\
$\mathrm{~F}\left(\mathrm{x}_{2}\right) 0.35$ & $\mathrm{Q}(0.35)$ & Dry & $0.15<\mathrm{x} \leq \mathrm{Q} 0.35$ \\
$\mathrm{~F}\left(\mathrm{x}_{3}\right) 0.50$ & $\mathrm{Q}(0.50)$ & Normal & $0.35<\mathrm{x}<\mathrm{Q} 0.65$ \\
$\mathrm{~F}\left(\mathrm{x}_{4}\right) 0.65$ & $\mathrm{Q}(0.65)$ & Rainy & $0.65 \leq \mathrm{x}<\mathrm{Q} 0.85$ \\
\hline $\mathrm{F}\left(\mathrm{x}_{5}\right) 0.85$ & $\mathrm{Q}(0.85)$ & Very rainy & $\mathrm{x} \geq 0.85$ \\
\hline
\end{tabular}

In this study the Quantis technique was used to determine dry and very dry years and to determine daily extreme rainfall by analyzing the variation of daily rainfall for the past period (1961-1990) and classifying both daily extreme rainfalls and annual precipitation averages for the future period (2011-2040). For an explanation of the practical application of functions in the Microsoft Excel Application, see Monteiro et. al. (2012).

\subsection{Determination of consecutive days with and without precipitation}

The determination of consecutive days with and without precipitation is useful for determining the trends of drought periods. To this end, the Microsoft Excel application was used following the methodology proposed in Figure 2. The functions used in the application, in the version in Portuguese, were SEERO, SE, E and CONT.SE.

From the application of the methodology shown in Figure 2, the following occurrences of rainfall were classified: i) number of days without precipitation between 5 and 9 days; ii) number of days without precipitation equal to or greater than 10 days. 


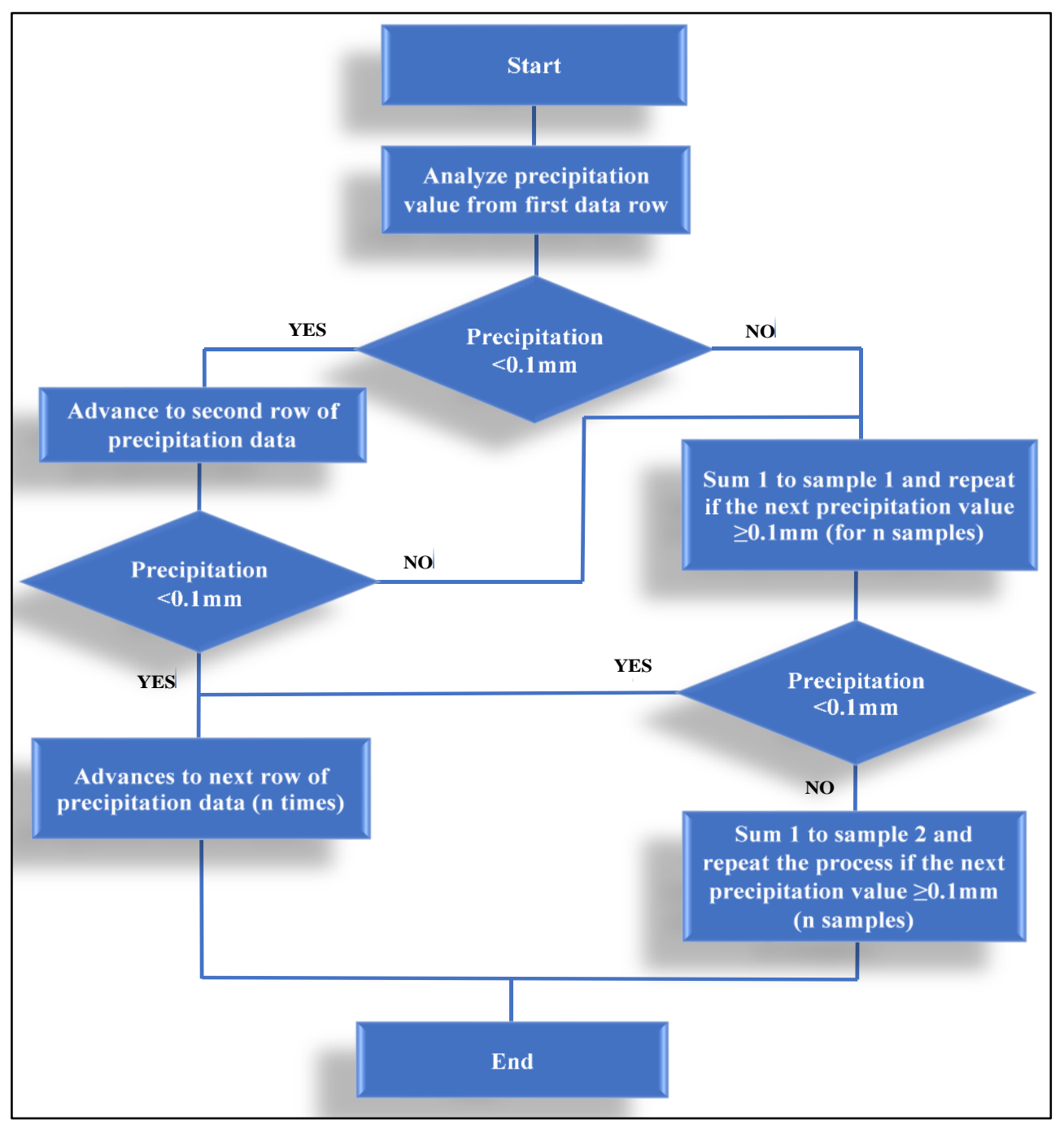

Figure 2. Methodology of counting days with and without precipitation.

\subsection{Pearson's coefficient of variation applied to precipitation variability}

Pearson's Coefficient of Variation is widely used in research because it is a technique for measuring the dispersion of data for a given sample and is used to describe the distribution of the data and its relationship between standard deviation and mean of a sample. The smaller the values of Pearson's Coefficient of Variation, the greater is the concentration of data around the sample mean (SILVESTRE, 2016), as observed in Equation 2.

$$
C V=\frac{S}{\bar{x}} \cdot 100
$$

Pearson's coefficient of variation was calculated for all rainfall simulation grids for the past (1961-1990) and future (2011-2040) periods and then compared between both periods to analyze within-period variability and its respective change between past and future periods.

\section{RESULTS AND DISCUSSION}

\subsection{Precipitation comparison between past and future periods}

The total average rainfall for the past period (1961-1990) for the climate simulation grids was $1346.2 \mathrm{~mm}$, with irregular spatial distribution throughout the Paraitinga and Paraibuna watershed. The variation of the average precipitation was to $1663.0 \mathrm{~mm}$ in the $\mathrm{P}_{10}$ grid, while the lowest average $(979.8 \mathrm{~mm})$ was observed in grid $\mathrm{P}_{5}$, with variation between the maximum

\section{IPABH}


and minimum precipitation grids of $41.1 \%$. The grids with the highest precipitation values were, respectively, $\mathrm{P}_{10}, \mathrm{P}_{2}, \mathrm{P}_{6}$ and $\mathrm{P}_{7}$, with these points located in the center and north of the Paraitinga and Paraibuna watershed, close to the border with the Paraiba do Sul watershed, in which these basins are inserted.

The points with the lowest precipitation indices were observed, respectively, in grids $\mathrm{P}_{5}$, $\mathrm{P}_{8}, \mathrm{P}_{3}$ and $\mathrm{P}_{1}$, located in the south of the study area, demonstrating that the Mar Sierra mountain formation causes high average windward precipitation rates due to orographic rainfall in oceanfacing municipalities such as Ubatuba/SP, which has an average precipitation of $2517.5 \mathrm{~mm}$ (INMET, 2019); this decreases the downwind precipitation values, as observed for grids $\mathrm{P}_{5}, \mathrm{P}_{8}$, $\mathrm{P}_{3}$ and $\mathrm{P}_{1}$. It is important to highlight that the average precipitation value for the study area in the past period of $1346.2 \mathrm{~mm}$ is compatible with the results obtained by Fisch (1995) and the climatological normal values in the municipality of Taubate/SP, which has an average precipitation of $1360.9 \mathrm{~mm}$ (INMET, 2019).

The average precipitation for the future period (2011-2040) is $1456.3 \mathrm{~mm}$, and the irregular distribution of precipitation is persistent for the analyzed period, demonstrating that the formation of the irregular relief, with the presence of mountains and hills (AB'SABER, 2003), generates a spatial irregularity in the distribution of precipitation, results that are similar to those obtained by Silva and Simões (2014). The simulation points with the highest precipitation values were, respectively, the grids $\mathrm{P}_{10}, \mathrm{P}_{2}, \mathrm{P}_{7}$ and $\mathrm{P}_{6}$, where the minimum average precipitation value was $1027.5 \mathrm{~mm}$ and the maximum was $1856.5 \mathrm{~mm}$, with a variation of $44.6 \%$ between precipitation extremes, values that are similar to results from Santos and Fisch (2016).

The points with the lowest precipitation values for the study area were, respectively, the grids $\mathrm{P}_{5}, \mathrm{P}_{8}, \mathrm{P}_{3}$ and $\mathrm{P}_{1}$, indicating that both the maximum and the minimum precipitation points remained almost unchanged. This demonstrates that there is a trend of continuity in the irregularity of rainfall distribution in the Paraitinga and Paraibuna watershed, following the same trend observed in the past period.

Analyzing the precipitation periods seasonally, the average rainfall for the rainy season in the study area from October to March in the past period was $958.7 \mathrm{~mm}$, while in the future period it was $1024.5 \mathrm{~mm}$, showing an increase between the analyzed periods of $6.9 \%$. In the summer period between December, January and February, the rainfall for the past period was $478.3 \mathrm{~mm}$, while in the future period it was $529.7 \mathrm{~mm}$, with an increase between the analyzed periods of $11.1 \%$. This fact demonstrates that rainfall tends to be concentrated in the summer period (DJF), which has the highest average monthly precipitation values, as shown in Figure 3.

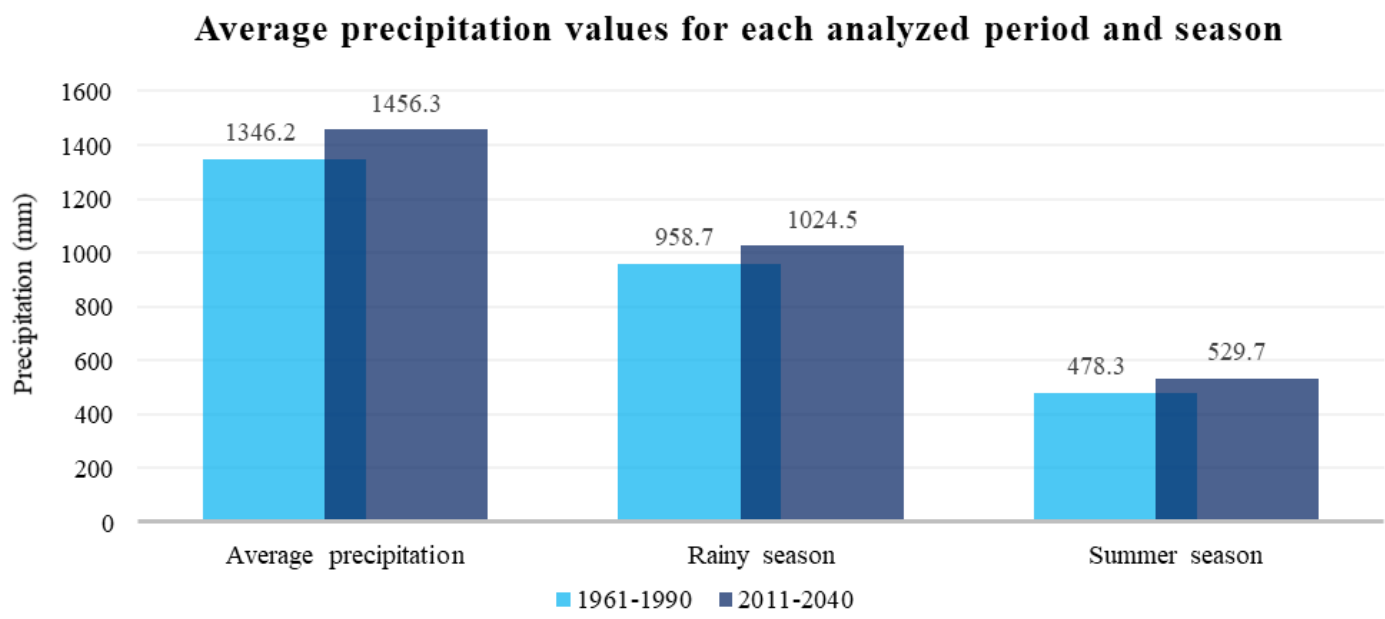

Figure 3. Comparison of average precipitation values for each analyzed period and season. 


\subsection{Identification of occurrence of dry and very dry years}

For the determination of dry and very dry years Quantis techniques were used and the parameters were established according to Table 1 . The precipitation of the past period was used to establish the parameters as observed in Table 2.

Table 2. Annual precipitation classification for the past period.

\begin{tabular}{ccc}
\hline Quantis & Classification & Variation \\
\hline Q $(0.15)$ & Very dry & $x \leq 1034.4 \mathrm{~mm}$ \\
Q $(0.35)$ & Dry & $1034.4 \mathrm{~mm} \leq \mathrm{x} \geq 1198.3 \mathrm{~mm}$ \\
$\mathrm{Q}(0.50)$ & Normal & $1198.3 \mathrm{~mm} \leq \mathrm{x} \geq 1321.3 \mathrm{~mm}$ \\
$\mathrm{Q}(0.65)$ & Rainy & $1321.3 \mathrm{~mm} \leq \mathrm{x} \geq 1444.3 \mathrm{~mm}$ \\
$\mathrm{Q}(0.85)$ & Very Rainy & $\mathrm{x} \geq 1444.3 \mathrm{~mm}$ \\
\hline
\end{tabular}

The results show that for the past period (1961-1990), there were 2 years classified as very dry, 5 years as dry, 5 years as normal, 11 years as rainy and 7 years as very rainy. The data reveal that there is a higher tendency of occurrence of rainy and very rainy years (18 occurrences) in detriment to the occurrence of dry or very dry years ( 7 occurrences).

In the future period (2011-2040), 1 very dry year, 2 dry years, 6 normal years, 5 rainy years and 16 very rainy years were observed. The data show that for the future period there will be a tendency for more frequent occurrence of rainy and very rainy years ( 21 occurrences), that is, an increase of $16.6 \%$ of this type of occurrence, while the occurrence of dry and very dry years will decrease by $-71.4 \%$. These data indicate that in the future period, due to more frequent rainy and very rainy years, there will be a tendency for an increase in the occurrence of natural disasters related to landslides in the study area, as the local topography is marked by the presence of hills and mountains, a trend similar to the results obtained by Mendes et al., (2018). Average precipitation data per period can be seen in Table 3.

Table 3. Precipitation values for each point (P1 ... P12) by period.

\begin{tabular}{|c|c|c|c|c|c|c|c|c|c|}
\hline \multirow[b]{2}{*}{ Point } & \multicolumn{2}{|c|}{$\begin{array}{l}\text { Average rainfall } \\
(\mathbf{m m})\end{array}$} & \multirow{2}{*}{$\begin{array}{c}\begin{array}{c}\text { Percent change } \\
\text { in precipitation } \\
\text { average }\end{array} \\
1961-1990 \text { to } \\
2011-2040\end{array}$} & \multicolumn{2}{|c|}{$\begin{array}{l}\text { Average rainfall in } \\
\text { the rainy season } \\
(\mathbf{m m})\end{array}$} & \multirow{2}{*}{$\begin{array}{c}\begin{array}{c}\text { Percent } \\
\text { change in } \\
\text { average } \\
\text { rainfall in the } \\
\text { rainy season }\end{array} \\
1961-1990 \text { to } \\
2011-2040\end{array}$} & \multicolumn{2}{|c|}{$\begin{array}{l}\text { Average rainfall } \\
\text { in the summer } \\
\text { period }(\mathrm{mm})\end{array}$} & \multirow{2}{*}{$\begin{array}{c}\begin{array}{c}\text { Percent change } \\
\text { in mean } \\
\text { precipitation in } \\
\text { summer }\end{array} \\
1961-1990 \text { to } \\
2011-2040\end{array}$} \\
\hline & $\begin{array}{c}1961- \\
1990\end{array}$ & $\begin{array}{l}2011- \\
2040\end{array}$ & & $\begin{array}{c}1961- \\
1990\end{array}$ & $\begin{array}{l}2011- \\
2040\end{array}$ & & $\begin{array}{c}1961- \\
1990\end{array}$ & $\begin{array}{l}2011- \\
2040\end{array}$ & \\
\hline $\mathbf{P}_{1}$ & 1265.8 & 1323.5 & $4.6 \%$ & 837.7 & 919.0 & $9.7 \%$ & 418.4 & 480.1 & $14.7 \%$ \\
\hline $\mathbf{P}_{2}$ & 1558.7 & 1710.8 & $9.8 \%$ & 1138.5 & 1222.1 & $7.3 \%$ & 575.6 & 633.5 & $10.1 \%$ \\
\hline $\mathbf{P}_{3}$ & 1157.8 & 1212.1 & $4.7 \%$ & 769.2 & 842.0 & $9.5 \%$ & 374.3 & 446.3 & $19.3 \%$ \\
\hline $\mathbf{P}_{4}$ & 1419.7 & 1550.6 & $9.2 \%$ & 1002.1 & 1090.7 & $8.8 \%$ & 509.6 & 574.1 & $12.6 \%$ \\
\hline $\mathbf{P}_{5}$ & 979.8 & 1027.5 & $4.9 \%$ & 646.5 & 666.8 & $3.1 \%$ & 308.7 & 336.2 & $8.9 \%$ \\
\hline $\mathbf{P}_{6}$ & 1474.6 & 1584.1 & $7.4 \%$ & 1010.3 & 1109.1 & $9.8 \%$ & 513.3 & 583.3 & $13.6 \%$ \\
\hline $\mathbf{P}_{7}$ & 1450.8 & 1607.8 & $10.8 \%$ & 1120.1 & 1181.0 & $5.4 \%$ & 565.1 & 608.5 & $7.7 \%$ \\
\hline $\mathbf{P}_{8}$ & 1056.5 & 1107.6 & $4.8 \%$ & 724.2 & 765.9 & $5.8 \%$ & 348.1 & 387.8 & $11.4 \%$ \\
\hline $\mathbf{P}_{9}$ & 1393.9 & 1514.4 & $8.6 \%$ & 1020.9 & 1088.9 & $6.7 \%$ & 504.3 & 555.4 & $10.1 \%$ \\
\hline $\mathbf{P}_{10}$ & 1663.0 & 1856.5 & $11.6 \%$ & 1257.9 & 1319.0 & $4.9 \%$ & 633.5 & 678.9 & $7.2 \%$ \\
\hline $\mathbf{P}_{12}$ & 1387.9 & 1525.1 & $9.9 \%$ & 1018.5 & 1065.0 & $4.6 \%$ & 510.8 & 542.6 & $6.2 \%$ \\
\hline Average & 1346.2 & 1456.3 & $7.8 \%$ & 958.7 & 1024.5 & $6.9 \%$ & 478.3 & 529.7 & $11.1 \%$ \\
\hline
\end{tabular}




\subsection{Determination of average extreme rainfall by simulation point.}

For the determination of daily extreme rainfall, the Quantis method was used, a technique identical to that used for the determination of dry and very dry years. When applying the technique to daily rainfall, data were classified according to Table 4.

Table 4. Classification of daily precipitation by Quantis technique.

\begin{tabular}{ccc}
\hline Quantis & Precipitation classification & Variation \\
\hline $\mathrm{Q}(0.15)$ & Very mild & $\mathrm{x} \leq 9.01 \mathrm{~mm}$ \\
$\mathrm{Q}(0.35)$ & Mild & $9.01 \mathrm{~mm} \leq \mathrm{x} \geq 20.9 \mathrm{~mm}$ \\
$\mathrm{Q}(0.50)$ & Normal & $20.9 \mathrm{~mm} \leq \mathrm{x} \geq 38.8 \mathrm{~mm}$ \\
$\mathrm{Q}(0.65)$ & Intense & $38.8 \mathrm{~mm} \leq \mathrm{x} \geq 50.7 \mathrm{~mm}$ \\
$\mathrm{Q}(0.85)$ & Very intense & $\mathrm{x} \geq 50.7 \mathrm{~mm}$
\end{tabular}

When analyzing the intense rainfall data its occurrence is irregular along the Paraitinga and Paraibuna rivers watershed; however, it is directly related to the simulation grids where the highest precipitation rates occur in the study area. For the past period, the areas where there was the highest occurrence of intense and very intense rainfall were in the simulation grids $\mathrm{P}_{10}$ (40 occurrences), $\mathrm{P}_{2}$ and $\mathrm{P}_{6}$ (30 occurrences) and $\mathrm{P}_{4}$ (24 occurrences), whereas the highest points occurrence of mild and very mild precipitation were the grids $\mathrm{P}_{8}$ ( 8 occurrences), $\mathrm{P}_{5}$ (10 occurrences), $\mathrm{P}_{3}$ (12 occurrences) and $\mathrm{P}_{12}$ (15 occurrences). The data reveal that the relief areas of hills and mountains are those with the highest incidence of heavy rainfall, demonstrating that these areas are the most prone to natural disasters and landslides related to heavy rainfall.

The future period (2011-2040) of rainfall distribution in the basins of the Paraitinga and Paraibuna Rivers was uneven, with the highest intensity rainfall being distributed almost unchanged over the study area compared to the past period. The grids with the highest occurrences of intense and very intense rainfall were $\mathrm{P}_{10}$ ( 66 occurrences), $\mathrm{P}_{6}$ ( 45 occurrences), $\mathrm{P}_{2}$ (41 occurrences) and $\mathrm{P}_{7}$ (35 occurrences). The grids with the highest occurrences of mild and very mild rainfall were $\mathrm{P}_{8}$ ( 7 occurrences), $\mathrm{P}_{5}$ (13 occurrences), $\mathrm{P}_{3}$ (15 occurrences) and $\mathrm{P}_{1}$ (23 occurrences). In all precipitation simulation grids, there was an increase in the occurrence of intense rainfall, with an average growth of $41.9 \%$, except for point $\mathrm{P}_{8}$, which had a decrease of $-12.5 \%$. The values obtained show that there will be an increase in the total of intense and very intense rains when compared to past and future periods, demonstrating that the frequency of occurrence of natural disasters and landslides will tend to increase in the region, mainly to the north of the study area, where there are hills and mountains with great slopes.

However, the maximum values of very intense precipitation do not show the occurrence of precipitation greater than $200.0 \mathrm{~mm}$ preceded by days with intense and very intense precipitation as occurred in São Luiz do Paraitinga/SP in 2010/01/01, which caused a great flood, destroying much of the historical and cultural heritage of the municipality (VERDE and SCHICCHI, 2013). The frequency of intense and very intense rainfall is shown in Table 5.

\subsection{Occurrence of drought periods}

To determine the frequency of drought, the frequency of occurrence was selected based on categories of 5 to 9 days without precipitation and 10 days or more without precipitation, comparing the past and future periods. The data show that in the past period there was an average of 296 occurrences of 5 to 9 days without precipitation and an average of 100 occurrences with 10 days or more without precipitation. The points $\mathrm{P}_{10}, \mathrm{P}_{2}, \mathrm{P}_{7}$ and $\mathrm{P}_{12}$ had the lowest occurrence of 5 to 9 days without precipitation, these being the grids with the highest precipitation in the study area, except for $\mathrm{P}_{12}$. For the occurrence of 10 days without precipitation, the grids with the lowest occurrence were $\mathrm{P}_{2}, \mathrm{P}_{4}, \mathrm{P}_{7}$ and $\mathrm{P}_{10}$, and for drought periods there was no relationship between total precipitation volumes and occurrence of days 
without precipitation.

Table 5. Occurrence and comparison of intense and very intense rainfall by period.

\begin{tabular}{cccccc}
\hline \multicolumn{2}{c}{ 1961-1990 } & \multicolumn{2}{c}{ 2011-2040 } & \multicolumn{2}{c}{ 1961-1990 to 2011-2040 } \\
\hline Grid & Occurrences & Grid & Occurrences & Grid & Percent Change \\
\hline $\mathrm{P}_{1}$ & 21 & $\mathrm{P}_{1}$ & 23 & $\mathrm{P}_{1}$ & 9.5 \\
$\mathrm{P}_{2}$ & 30 & $\mathrm{P}_{2}$ & 41 & $\mathrm{P}_{2}$ & 36.7 \\
$\mathrm{P}_{3}$ & 12 & $\mathrm{P}_{3}$ & 15 & $\mathrm{P}_{3}$ & 25.0 \\
$\mathrm{P}_{4}$ & 24 & $\mathrm{P}_{4}$ & 31 & $\mathrm{P}_{4}$ & 29.2 \\
$\mathrm{P}_{5}$ & 10 & $\mathrm{P}_{5}$ & 13 & $\mathrm{P}_{5}$ & 30.0 \\
$\mathrm{P}_{6}$ & 30 & $\mathrm{P}_{6}$ & 45 & $\mathrm{P}_{6}$ & 50.0 \\
$\mathrm{P}_{7}$ & 20 & $\mathrm{P}_{7}$ & 35 & $\mathrm{P}_{7}$ & 75.0 \\
$\mathrm{P}_{8}$ & 8 & $\mathrm{P}_{8}$ & 7 & $\mathrm{P}_{8}$ & -12.5 \\
$\mathrm{P}_{9}$ & 15 & $\mathrm{P}_{9}$ & 28 & $\mathrm{P}_{9}$ & 86.7 \\
$\mathrm{P}_{10}$ & 40 & $\mathrm{P}_{10}$ & 66 & $\mathrm{P}_{10}$ & 65.0 \\
$\mathrm{P}_{12}$ & 15 & $\mathrm{P}_{12}$ & 25 & $\mathrm{P}_{12}$ & 66.7 \\
\hline Average & 20.5 & Average & 29.9 & Average & 41.9 \\
\hline
\end{tabular}

For the future period, an average of 299 occurrences of 5 to 9 days without precipitation were observed, while there were 93 occurrences of 10 days or more without precipitation. This represents an increase of $1.2 \%$ in the occurrence of 5 to 9 days without precipitation and a $7.5 \%$ decrease for 10 days or more without precipitation compared to the past period. For the occurrence of 5 to 9 days without precipitation, the lowest number of occurrences were observed in the grids $\mathrm{P}_{10}, \mathrm{P}_{12}, \mathrm{P}_{7}$ and $\mathrm{P}_{2}$, and these grids are those with the greatest precipitation in the study area, except for $\mathrm{P}_{12}$. The occurrence of 10 days or more without precipitation occurred less frequently at points $\mathrm{P}_{2}, \mathrm{P}_{10}, \mathrm{P}_{4}$ and $\mathrm{P}_{7}$, behaving similarly to the past period where there was no relationship between the points of greatest precipitation and the occurrence of drought over 10 days or more without precipitation.

When comparing the past and future periods it is observed that there will be a tendency to maintain periods of 5 to 9 days without precipitation, while there will be a decrease in drought periods of 10 days or more without precipitation. This demonstrates that when relating the average total precipitation values and the occurrence of days of intense and very intense precipitation, there will be a tendency of concentration of extreme events in the rainy period for the future (2011-2040). Data on days without precipitation can be seen in Table 6 .

\subsection{Spatial variability of precipitation}

The results for the Pearson's Coefficient of Variation analysis of the spatial variability of precipitation for each climate simulation point show that for the past period (1961-1990) the greatest spatial variability is found in grids $\mathrm{P}_{5}(19.1 \%), \mathrm{P}_{8}(18.4 \%), \mathrm{P}_{3}(18.1 \%)$ and $\mathrm{P}_{1}(17.3 \%)$, with these points being those with the lowest average precipitation. The grids with the least variability are found in grids $\mathrm{P}_{10}(13.6 \%), \mathrm{P}_{2}(14.8 \%), \mathrm{P}_{12}(15.2 \%)$ and $\mathrm{P}_{7}(15.4 \%)$, compatible with the points of greatest precipitation in the area, except grid $\mathrm{P}_{12}$. These results show that the grids with the highest rainfall have less variability, revealing that in these areas rainfall is homogeneous and more intense, explaining that the northern region of the study area is more susceptible to extreme weather events and natural disasters. 
Table 6. Occurrence of days without precipitation and comparison between periods.

\begin{tabular}{|c|c|c|c|c|c|c|}
\hline & \multicolumn{2}{|c|}{ 1961-1990 } & \multicolumn{2}{|c|}{ 2011-2040 } & \multicolumn{2}{|c|}{$1961-1990$ to $2011-2040$} \\
\hline & $\begin{array}{l}5 \text { to } 9 \\
\text { days }\end{array}$ & $\begin{array}{l}10 \text { days } \\
\text { or more }\end{array}$ & $\begin{array}{l}5 \text { to } 9 \\
\text { days }\end{array}$ & $\begin{array}{l}10 \text { days } \\
\text { or more }\end{array}$ & $\begin{array}{c}\text { Percentage } \\
\text { variation: } 5 \text { to } 9 \\
\text { days }\end{array}$ & $\begin{array}{c}\text { Percentage } \\
\text { variation: } 10 \text { days or } \\
\text { more }\end{array}$ \\
\hline $\mathrm{P}_{1}$ & 313 & 105 & 319 & 96 & $1.9 \%$ & $-8.6 \%$ \\
\hline $\mathrm{P}_{2}$ & 261 & 90 & 288 & 86 & $10.3 \%$ & $-4.4 \%$ \\
\hline $\mathrm{P}_{3}$ & 320 & 111 & 327 & 98 & $2.2 \%$ & $-11.7 \%$ \\
\hline $\mathrm{P}_{4}$ & 288 & 92 & 308 & 87 & $6.9 \%$ & $-5.4 \%$ \\
\hline $\mathrm{P}_{5}$ & 348 & 110 & 326 & 106 & $-6.3 \%$ & $-3.6 \%$ \\
\hline $\mathrm{P}_{6}$ & 300 & 103 & 313 & 90 & $4.3 \%$ & $-12.6 \%$ \\
\hline $\mathrm{P}_{7}$ & 275 & 92 & 282 & 88 & $2.5 \%$ & $-4.3 \%$ \\
\hline $\mathrm{P}_{8}$ & 329 & 108 & 316 & 98 & $-4.0 \%$ & $-9.3 \%$ \\
\hline $\mathrm{P}_{9}$ & 292 & 102 & 295 & 94 & $1.0 \%$ & $-7.8 \%$ \\
\hline $\mathrm{P}_{10}$ & 253 & 93 & 251 & 86 & $-0.8 \%$ & $-7.5 \%$ \\
\hline $\mathrm{P}_{12}$ & 279 & 101 & 271 & 94 & $-2.9 \%$ & $-6.9 \%$ \\
\hline Average & 296 & 100 & 299 & 93 & $1.2 \%$ & $-7.5 \%$ \\
\hline
\end{tabular}

In the future period (2011-2040) the highest spatial variability of precipitation is found in grids $\mathrm{P}_{5}(21.2 \%), \mathrm{P}_{3}(20.3 \%), \mathrm{P}_{1}(20.2 \%)$ and $\mathrm{P}_{8}(20.1 \%)$, showing considerable variation in the indices compared to the past period (1961-1990); however, the grids with the lowest rainfall persisted. The grids with the lowest precipitation variability are $\mathrm{P}_{10}(15.7), \mathrm{P}_{12}(16.1 \%), \mathrm{P}_{7}$ (17.4\%) and $\mathrm{P}_{2}(17.6 \%)$, and those with the highest precipitation have the lowest spatial variability of precipitation, except grid $\mathrm{P}_{12}$, demonstrating the tendency to maintain the area of occurrence of natural disasters and extreme events in the northern region of the study area.

The comparison between past and future periods shows that at all points there will be an increase in spatial variability in precipitation as there is an increase in total precipitation averages for the analyzed periods, demonstrating that the highest precipitation values per grid are related to the lowest spatial variability of precipitation. These data are shown in Table 7 .

Table 7. Pearson's coefficient of variation for simulated precipitation points.

\begin{tabular}{lccc}
\hline & Pearson coefficient of variation & Percentage variation of Pearson coefficient of variation \\
\hline & $1961-1990$ & $2011-2040$ & $1961-1990$ to $2011-2040$ \\
\hline $\mathbf{P}_{\mathbf{1}}$ & $17.3 \%$ & $20.2 \%$ & $17.1 \%$ \\
$\mathbf{P}_{\mathbf{2}}$ & $14.8 \%$ & $17.6 \%$ & $18.6 \%$ \\
$\mathbf{P}_{\mathbf{3}}$ & $18.1 \%$ & $20.3 \%$ & $12.5 \%$ \\
$\mathbf{P}_{\mathbf{4}}$ & $15.5 \%$ & $17.8 \%$ & $14.8 \%$ \\
$\mathbf{P}_{\mathbf{5}}$ & $19.1 \%$ & $21.2 \%$ & $11.0 \%$ \\
$\mathbf{P}_{\mathbf{6}}$ & $16.7 \%$ & $18.6 \%$ & $11.5 \%$ \\
$\mathbf{P}_{\mathbf{7}}$ & $15.4 \%$ & $17.4 \%$ & $12.8 \%$ \\
$\mathbf{P}_{\mathbf{8}}$ & $18.4 \%$ & $20.1 \%$ & $9.2 \%$ \\
$\mathbf{P}_{\mathbf{9}}$ & $17.1 \%$ & $18.8 \%$ & $10.0 \%$ \\
$\mathbf{P}_{\mathbf{1 0}}$ & $13.6 \%$ & $15.7 \%$ & $15.7 \%$ \\
$\mathbf{P}_{\mathbf{1 2}}$ & $15.2 \%$ & $16.1 \%$ & $5.4 \%$ \\
\hline
\end{tabular}

\section{CONCLUSIONS}

Analyzing the rainfall simulated by the HadCM3 model for the Paraitinga and Paraibuna River's watershed, considering the past (1961-1990) and future periods (2011-2040), it was observed that there will be an increase of precipitation, with a concentration of rainfall in the summer period (DJF). There will be an increase of $41.9 \%$ in intense and very intense rainfall 
compared to past and future periods, with more frequent rainfall occurring in the mountainous areas of the study area, indicating a tendency for increased natural disasters related to rainfall, especially those related to landslides, considering the topography of the region.

There will be a tendency for a decrease of $7.5 \%$ in drought periods of 10 days or more without precipitation, followed by an increase in spatial variability of precipitation when past and future periods are compared, indicating a trend in the summer of larger extreme events followed by natural disasters.

\section{REFERENCES}

AB'SÁBER, A. N. Os domínios de natureza no Brasil: potencialidades paisagísticas. Ateliê Editorial, 2003.

CHOU, S. C. et al. Assessment of climate change over South America under RCP 4.5 and 8.5 downscaling scenarios. American Journal of Climate Change, v. 3, n. 5, p. 512-525, 2014.

FISCH, G. Caracterização climática e balanço hídrico de Taubaté (SP). Revista Biociências, Taubaté, v. 1, n. 1, p. 81-90, 1995.

HORIKOSHI, A. S.; FISCH, G. F. Balanço hídrico atual e simulações para cenários climáticos futuros no município de Taubaté, SP, Brasil. Revista Ambiente \& Água, Taubaté, v.2, n.2, p. 33-46, 2007.

INMET - Instituto Nacional de Meteorologia. Normais climatológicas (1981-2010). Disponível

em: <http://www.inmet.gov.br/portal/index.php?r=clima/normaisClimatologicas>. Acesso em: 20 de setembro de 2019.

IPCC. Intergovernamental Panel on Climate Change. Fouth Assesment Report Climate change 2007: the physical science basis. Disponível em: $<$ https://www.ipcc.ch/site/assets/uploads/2019/08/Edited-

SPM_Approved_Microsite_FINAL.pdf >. Acesso em 12 de outubro de 2019.

IPCC. Intergovernmental Panel on Climate Change. Climate Change and Land. Disponível em: < https://www.ipcc.ch/reports/> acesso em 12 de outubro de 2019.

LYRA, A et al. Climate change projections over three metropolitan regions in Southeast Brazil using the non-hydrostatic Eta regional climate model at 5-km resolution. Theoretical and applied climatology, v. 132, n. 1-2, p. 663-682, 2018.

MENDES, R. M.; ANDRADE, M. R. M.; GRAMINHA, C. A.; PRIETO, C. C.; ÁVILA, F. F.; CAMARINHA, P. I. M. Stability Analysis on Urban Slopes: Case Study of an Anthropogenic-Induced Landslide in São José dos Campos, Brazil. Geotechnical and Geological Engineering, v. 36, p. 599-610, 2018.

MONTEIRO, J. B.; ROCHA, A. B.; ZANELLA, M. E. Técnica dos Quantis para caracterização de anos secos e chuvosos (1980-2009): baixo curso do Apodi-Mossoró/RN. Revista do Departamento de Geografia, v. 23, p. 232-249, 2012.

PINKAYAN, S. Conditional probabilities of occurrence of wet and dry years over a large continental area. Forty-Collins. Colorado-USA: Hydrology Colorado State University, 1966. (Paper. Number 12). 
SILVA, W.M. \& SIMÕES, S.J.C. Spatial Intra-Annual Variability of Precipitation Based on Geostatistics. A Case Study for the Paraiba Do Sul Basin, Southeastern Brazil. International Journal of Geosciences, 5, p. 408-417, 2014.

TEIXEIRA, W., FAIRCHILD, T. R., TOLEDO, M. C. M., TAIOLI, F. Decifrando a Terra. Companhia Editora Nacional, 2a ed., São Paulo, 2009.

SANTOS, T. A.; FISCH, G. Temperatura e precipitação: futuros cenários do município de Taubaté, SP, Brasil. Revista Ambiente \& Água, v. 11, p. 1068-1087, 2016.

SILVA, R. C.; FISCH, G. Cenários hidroclimáticos futuros (2011-2040) para a represa de Paraibuna, SP, Brasil: subsídios para a transposição entre bacias hidrográficas. Geociências, v. 38, n. 2, p. 587-597, 2019.

SILVESTRE, M. R. Técnicas estatísticas utilizadas em climatologia geográfica: diagnóstico e propostas. 2016. 408p. Tese de Doutorado em Geografia. Universidade Estadual Paulista, Presidente Prudente.

VERDE, P. F.; SCHICCHI, M. C. S. São Luiz do Paraitinga: da reconstrução Pós-enchente às Políticas de Prevenção e Conservação Urbana. Cadernos de Pós-Graduação em Arquitetura e Urbanismo, v. 13, n. 1, p. 25, 2013.

USGS. United States Geological Survey. Earth Explorer. Disponível em: <https://earthexplorer.usgs.gov/>. Acesso em: 28 de setembro de 2019.

XAVIER, T. M. B. S; XAVIER, A. F. S; ALVES, J. M. B. Quantis e eventos extremos: aplicações em ciências da terra e ambientais. Fortaleza: RDS, 2007. 278 p. 